\title{
НАСЛІДКИ ВАГІТНОСТІ, ПОЛОГІВ, СТАН НОВОНАРОДЖЕНИХ У ЖІНОК I3 НЕВИНОШУВАННЯМ, ЯКИМ ПРОВОДИЛИ МЕТАБОЛІЧНУ КОРЕКЦІЮ
}

\author{
В.В. КУДІНОВА \\ кафедра акушерства та \\ гінекології № 2 Харківської \\ медичної академії \\ післядипломної освіти \\ (завідувач - д.мед.н., \\ професор Козуб М.І.)
}

$\mathrm{Y}_{\mathrm{r}}^{\mathrm{m}}$ проблемі невиношування вагітності перинатальний аспект $є$ головним як з медичної, так і з соціальних позицій. Загроза переривання вагітності, що супроводжується порушенням функції фретоплацентарної системи (ФПС), може призводити до затримки функціонального й морфологічного дозрівання плода, порушення його компенсаторно-пристосувальних механізмів, розвитку дезадаптаційного синдрому в немовляти і є причиною підвищення частоти перинатальної смертності, пороків розвитку, відхилень у психосоматичному розвитку дітей [1-3].

Дослідження багатьох учених показали, що для дітей, які народилися в матерів з порушенням ФПС при загрозі переривання вагітності в III триместрі, навіть при народженні в задовільному стані і з нормальними фізичними показниками, характерні більш пізнє відновлення первісної маси, пізнє відпадання пуповинного залишку, диспротеїнемія, зниження рівня імуноглобулінів [1, 2]. Внаслідок несприятливого впливу загрозливого аборту на матково-плацентарний кровотік (МПК) і розвиток плода загибель недоношених дітей у 17 разів перевищувала перинатальну смертність доношених, склавши відповідно 35 і 22\%. Особливо несприятливі як для доношених, так і для недоношених дітей наслідки загрозливого аборту, перенесеного в перші 14 тиж вагітності. Так, загрозливий аборт у перші 14 тиж вагітності мав місце у $37 \%$ жінок, що народили дітей з дитячим церебральним паралічем, а у контрольній групі - в 6,8\% жінок [3]. Найбільша перинатальна смертність виявлена в групі пацієнток, що мали кров'янисті виділення в I триместрі вагітності; при загрозі викидня, що супроводжувалася кров'янистими виділеннями, частота неврозів у дітей була вище в 10 разів, а олігофренії - в 3 рази $[1,2]$. Тому вивчення і впровадження нових, більш ефективних способів профрілактики і лікування загрози невиношування вагітності й ускладнення ії̈ плацентарною недостатністю $є$ одним із найважливіших завдань сучасного акушерства [1, 2].

Метою дослідження було вивчення наслідків вагітності, пологів, стан немовляти в ранньому неонатальному періоді, матерям яких застосовували схеми метаболічної корекції
(MK) для профрілактики та лікування загрози невиношування вагітності й ускладнення їі плацентарною недостатністю.

\section{МАТЕРІАЛИ ТА МЕТОДИ ДОСЛІДЖЕННЯ}

Проаналізовано результати 480 пацієнток. Першу досліджувану групу становили 180 жінок, в анамнезі яких було два і більше мимовільних абортів чи передчасних пологів, ускладнених плацентарною недостатністю. Друга група складалася з 200 жінок зі звичним перериванням вагітності, в анамнезі у яких було два і більше мимовільних абортів чи передчасних пологів, але вагітність не була ускладнена плацентарною недостатністю. До групи контролю входили 100 соматично здорових вагітних, які мали в анамнезі одні і більше своєчасних пологів. У першій групі 78,9\% жінок були старше 30 років, у другій - таких жінок було 64 (32,0\%), у контрольній - чотири (4,0\%).

Вагітні першої і другої груп одержували комплексне індивідуально підібране патогенетичне лікування (спазмолітики, диференційовану гормональну корекцію, токолітичні засоби).

Експериментальні дослідження, проведені нами, доводять ефективність застосування MK. У зв'язку з цим ми застосовували курси MK, які поділили на два комплекси препаратів метаболічної дії. До першого комплексу препаратів належать кофрактори і субстрати основної ланки метаболізму циклу Кребса: тіамінофосфат, ліпоєва кислота, кальцію пантотенат, рибофрлавіну мононуклеотид, $\alpha$-токоферолу ацетат. Розлади тканинної біоенергетики зазвичай зумовлюють порушення процесів анаболізму, тому використання активаторів циклу Кребса більш ефективне у поєднанні з призначенням стимуляторів біосинтетичних процесів (другий комплекс препаратів): рибоксину, оротату калію, піридоксальфоссрату, фролієвої кислоти, гліцерофросфрату кальцію, карнітину. Необхідність послідовного застосування обох комплексів зумовлена тим, що клінічна ефективність препаратів анаболічної дії другого комплексу підвищується при достатньому резерві ендогенних макроенергетичних з'єднань, продукція яких зростає при посиленні фрункції циклу Кребса (дія препаратів першого комплексу). Кожний комплекс застосовували протягом 5-7 


\begin{tabular}{|c|c|c|c|c|c|c|c|c|c|c|c|c|c|c|}
\hline \multirow{3}{*}{$\begin{array}{l}\text { Клінічні } \\
\text { групи } \\
\text { вагітних }\end{array}$} & \multirow{2}{*}{\multicolumn{2}{|c|}{$\begin{array}{c}\text { Несвоєчасне } \\
\text { вилиття } \\
\text { навколоплідних } \\
\text { вод }\end{array}$}} & \multirow{2}{*}{\multicolumn{2}{|c|}{$\begin{array}{l}\text { Аномалія } \\
\text { зганяючих } \\
\text { сил }\end{array}$}} & \multirow{2}{*}{\multicolumn{2}{|c|}{$\begin{array}{c}\text { Гіпоксія } \\
\text { плода } \\
\text { і асфіксія } \\
\text { немовлят }\end{array}$}} & \multicolumn{8}{|c|}{ Оперативне розродження } \\
\hline & & & & & & & \multicolumn{2}{|c|}{ Кесарів розтин } & \multicolumn{2}{|c|}{$\begin{array}{c}\text { Акушерські } \\
\text { щипці }\end{array}$} & \multicolumn{2}{|c|}{$\begin{array}{c}\text { Внутрішньо- } \\
\text { маткові операції } \\
3 \text { приводу } \\
\text { кровотечі }\end{array}$} & \multicolumn{2}{|c|}{$\begin{array}{c}\text { Операції, що } \\
\text { поновлюють } \\
\text { пологові } \\
\text { шляхи }\end{array}$} \\
\hline & число & $\%$ & число & $\%$ & число & $\%$ & число & $\%$ & число & $\%$ & число & $\%$ & число & $\%$ \\
\hline $\begin{array}{c}\text { Перша група (звичне невиношу- } \\
\text { вання, ускладнене плацентар- } \\
\text { ною недостатністю, } n=180 \text { ) }\end{array}$ & - & - & 7 & 3,9 & - & - & 37 & 20,6 & 2 & 1,1 & 39 & 21,7 & 78 & 43,3 \\
\hline $\begin{array}{c}1.1 \text { підгрупа (MK + основне } \\
\text { лікування, } n=90)\end{array}$ & - & - & 3 & 1,7 & - & - & 19 & 10,6 & 2 & 1,1 & 19 & 10,6 & 20 & 11,1 \\
\hline $\begin{array}{c}1.2 \text { підгрупа (основне } \\
\text { лікування, } n=90 \text { ) }\end{array}$ & - & - & 4 & 2,2 & - & - & 18 & 10,0 & - & - & 20 & 11,1 & 58 & 32,2 \\
\hline $\begin{array}{c}\text { Друга група (звичне невино- } \\
\text { шування, } n=200 \text { ) }\end{array}$ & - & - & 8 & 4,0 & - & - & 20,0 & 10,0 & 1 & 0,5 & 41 & 20,5 & 80 & 40,0 \\
\hline $\begin{array}{c}2.1 \text { підгрупа (MK + основне } \\
\text { лікування, } n=100)\end{array}$ & - & - & 2 & 1,0 & - & - & 9,0 & 4,5 & - & - & 17 & 8,5 & 20 & 10,0 \\
\hline $\begin{array}{c}2.2 \text { підгрупа (основне } \\
\text { лікування, } n=100 \text { ) }\end{array}$ & - & - & 6 & 3,0 & - & - & 11,0 & 5,5 & 1 & 0,5 & 24 & 12,0 & 60 & 30,0 \\
\hline
\end{tabular}

днів, причому метаболічні комплекси рекомендується використовувати послідовно упродовж 10-14 днів з інтервалом 2-3 тиж.

Схема застосування метаболічних комплексів:

- Перший комплекс: кокарбоксилаза 100 мг внутрішньо один раз на день; рибофрлавіну мононуклеотид - 1\% по 1,0 мл внутрішньом'язово; пантотенат кальцію - 0,2 г тричі на день; ліпоєва кислота - 0,025 г тричі на день; $\alpha$-токоферолу ацетат - по 1 капсулі двічі на день.

- Другий комплекс: 0,2 г рибоксину, 0,02 г піридоксальфоссрату, 0,001 г фолієвої кислоти, 0,25 г гліцерофросфрату кальцію, 0,25 г оротату калію (кожний з препаратів призначали тричі на день).

Жінкам і немовлятам проводили загальноприйняті клініко-лабораторні обстеження. Активність сукцинатдегідрогенази (СДГ) і $\alpha$-гліцерофоссратдегідрогенази ( $\alpha$-ГФДГ) визначали кількісним цитохімічним методом. Статистичну обробку результатів проводили за допомогою стандартного програмного забезпечення.

\section{РЕЗУЛЬТАТИ ДОСЛІДЖЕННЯ ТА ЇХ ОБГОВОРЕННЯ}

Проспективні групи дослідження: першу групу поділили на підгрупу 1.1 - вагітні, яким здійснювали МK + патогенетичне лікування «основного лікування» і підгрупу 1.2 - вагітні «основного лікування». Другу групу поділили на підгрупу 2.1 - вагітні, які отримували MK + «основне лікування» і підгрупу 2.2 - вагітні «основного лікування».

При розгляді наслідків вагітності і пологів виявлено, що вагітність у всіх зазначених групах закінчилася своєчасними пологами на строках 38-40 тиж. Характеристика перебігу пологово- го акту представлена в таблиці 1. Так, у першій групі зі звичним невиношуванням, ускладненим плацентарною недостатністю, у 37 (20,6\%) жінок пологи закінчилися шляхом операції кесарева розтину, з них: у 1.1 підгрупі - 19 (10,6\%), у 1.2 підгрупі - 18 (10,0\%) жінок. У другій групі зі звичним невиношуванням кесарів розтин зроблено 20,0 (10,0\%) пацієнткам, з них: у 2.1 підгрупі - 9 (4,5\%), у 2.2 підгрупі - 11 (5,5\%) жінкам.

Отже, в першій групі операцію кесарів розтин було виконано майже у кожної 5-ї жінки, у другій групі - у кожної 10-ї, незалежно від обраного методу лікування. Показаннями до кесарева розтину здебільшого були: анатомічно вузький таз, аномалія зганяючих сил, повне передлежання плаценти. В обох групах у кожної 5-ї жінки проведена внутрішньоматкова операція з приводу кровотечі. Перебіг післяпологового та післяопераційного періодів у породілей проходив без ускладнень. Випадків пологового травматизму не виявлено.

В усіх випадках стан немовляти оцінювали за шкалою Апгар, і в обох проспективних групах новонароджені мали на першій та п'ятій хвилині життя оцінку 8-10 балів. Випадків асфіксій і антенатальної смерті не було. Середній зріст немовляти у 1.1 підгрупі склав 52,0 \pm 3,12 см, у

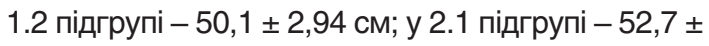
3,37 см і в 2.2 підгрупі - 51,2 + 3,17 см. Розподіл немовлят за масою тіла представлено в таблиці 2. Маса немовлят була вище в підгрупах, які одержували MK $(p<0,05)$.

При оцінці перебігу раннього неонатального періоду в дітей, матері яких одержували MK, зареєстрований фрізіологічний надлишок маси тіла (менше 6\% первісної), в інших, які отримували тільки патогенетичне лікування,
ПОРІВНЯЛЬНА ХАРАКТЕРИСТИКА ПЕРЕБІГУ ПОЛОГІВ У ВАГІТНИХ ПРОСПЕКТИВНИХ ГРУП В ЗАЛЕЖНОСТІ ВІД ВИБОРУ МЕТОДУ ЛІКУВАННЯ 
ТАБЛИЦЯ 2.

\begin{tabular}{|c|c|c|c|c|c|c|c|c|c|c|c|c|c|c|c|c|}
\hline \multirow{3}{*}{$\begin{array}{c}\text { Клінічні } \\
\text { групи вагітних }\end{array}$} & \multirow{2}{*}{\multicolumn{2}{|c|}{ К-сть вагітних }} & \multicolumn{14}{|c|}{ Маса немовлят, г } \\
\hline & & & \multicolumn{2}{|c|}{ до 1500} & \multicolumn{2}{|c|}{$1501-2000$} & \multicolumn{2}{|c|}{$2001-2500$} & \multicolumn{2}{|c|}{$2501-3000$} & \multicolumn{2}{|c|}{$3001-3500$} & \multicolumn{2}{|c|}{$3501-4000$} & \multicolumn{2}{|c|}{ більше 4001} \\
\hline & число & $\%$ & число & $\%$ & число & $\%$ & число & $\%$ & число & $\%$ & число & $\%$ & число & $\%$ & число & $\%$ \\
\hline $\begin{array}{c}\text { Перша група (звичне } \\
\text { невиношування, усклад- } \\
\text { нене плацентарною } \\
\text { недостатністю, } \\
\text { n=180) }\end{array}$ & 180 & 100 & - & - & - & - & - & - & 9 & 5 & 77 & 42,8 & 94 & 52,2 & - & - \\
\hline $\begin{array}{c}1.1 \text { підгрупа (МК + } \\
\text { основне лікування, } \\
n=90)\end{array}$ & 90 & 50 & - & - & - & - & - & - & 2 & 1,1 & 37 & 20,6 & 51 & 28,3 & - & - \\
\hline $\begin{array}{c}1.2 \text { підгрупа (основне } \\
\text { лікування, } \mathrm{n}=90 \text { ) }\end{array}$ & 90 & 50 & - & 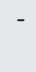 & - & - & - & - & 7 & 3,9 & 40 & 22,2 & 43 & 23,9 & - & - \\
\hline $\begin{array}{l}\text { Друга група (звичне не- } \\
\text { виношування, } \mathrm{n}=200 \text { ) }\end{array}$ & 200 & 100 & - & - & - & - & - & - & 5 & 2,5 & 71 & 35,5 & 121 & 60,5 & 3 & 1,5 \\
\hline $\begin{array}{c}2.1 \text { підгрупа (МК + } \\
\text { основне лікування, } \\
n=100)\end{array}$ & 100 & 50 & - & - & - & - & - & - & - & - & 25 & 12,5 & 72 & 36,0 & 3 & 1,5 \\
\hline $\begin{array}{c}2.2 \text { підгрупа (основне } \\
\text { лікування, } \mathrm{n}=100 \text { ) }\end{array}$ & 100 & 50 & - & - & - & - & - & - & 5 & 2,5 & 46 & 23,0 & 49 & 24,5 & - & - \\
\hline
\end{tabular}

ТАБЛИЦЯ 2.

РОЗПОДІЛ НЕМОВЛЯТ

ДОСЛІДЖУВАНИХ ГРУП ЗА МАСОЮ

ТІЛА В ЗАЛЕЖНОСТІ ВІД ВИБРАНОГО

МЕТОДУ ЛІКУВАННЯ

втрата маси плода склала 6-8\% і відбувалося більш пізніше відновлення первісної маси тіла. При цьому в немовлят, народжених шляхом кесарева розтину, відмічена середня, низька чи висока втрата маси. Надлишок маси тіла не залежав від оцінки за шкалою Апгар.
Перебіг раннього неонатального періоду в дітей, матері яких одержували MK, характеризувався більш м'яким періодом адаптації. Так, у підгрупах 1.1 і 2.1 мало місце більш раннє відпадання пуповинного залишку (на 6-ту добу), чим у підгрупах 1.2 і 2.2.

ТАБЛИЦя 3.

\begin{tabular}{|c|c|c|c|c|c|}
\hline $\begin{array}{c}\text { Доба неонатального } \\
\text { періоду }\end{array}$ & Клінічні групи & Гемоглобін, г/л & Гематокрит, \% & $\begin{array}{c}\text { Глюкоза крові, } \\
\text { ммоль/л }\end{array}$ & $\begin{array}{c}\text { Сечовина крові, } \\
\text { мкмоль/л }\end{array}$ \\
\hline \multirow{5}{*}{ Перша } & Контрольна група ( $\mathrm{n}=100)$ & $211,0 \pm 12,02$ & $65,0 \pm 3,72$ & $3,3 \pm 0,20$ & $3,7 \pm 0,22$ \\
\hline & 1.1 підгрупа (n = 90) & $210,7 \pm 11,56^{1}$ & $66,7 \pm 3,76^{1}$ & $3,3 \pm 0,18^{1}$ & $3,9 \pm 0,23^{1}$ \\
\hline & 1.2 підгрупа ( $\mathrm{n}=90)$ & $212,3 \pm 12,23^{2}$ & $68,2 \pm 3,85^{2}$ & $3,0 \pm 0,16^{2}$ & $4,0 \pm 0,22^{2}$ \\
\hline & 2.1 підгрупа ( $\mathrm{n}=100)$ & $211,2 \pm 12,053$ & $65,0 \pm 3,713$ & $3,3 \pm 0,223$ & $3,7 \pm 0,223$ \\
\hline & 2.2 підгрупа (n = 100) & $213,0 \pm 12,354$ & $67,8 \pm 3,944$ & $2,9 \pm 0,154$ & $3,9 \pm 0,234$ \\
\hline \multirow{5}{*}{ Третя } & Контрольна група ( $\mathrm{n}=100)$ & $203,0 \pm 11,38$ & $60,0 \pm 3,36$ & $3,7 \pm 0,21$ & $4,5 \pm 0,24$ \\
\hline & 1.1 підгрупа (n = 90) & $202,0 \pm 11,31^{1}$ & $60,7 \pm 3,46^{1}$ & $3,7 \pm 0,24^{1}$ & $4,7 \pm 0,27^{1}$ \\
\hline & 1.2 підгрупа ( $n=90)$ & $204,1 \pm 11,22^{2}$ & $62,0 \pm 3,39^{2}$ & $3,3 \pm 0,18^{2}$ & $4,6 \pm 0,27^{2}$ \\
\hline & 2.1 підгрупа $(n=100)$ & $202,0 \pm 11,513$ & $60,9 \pm 3,413$ & $3,7 \pm 0,223$ & $4,6 \pm 0,243$ \\
\hline & 2.2 підгрупа (n = 100) & $205,2 \pm 11,484$ & $61,1 \pm 3,484$ & $3,4 \pm 0,194$ & $4,9 \pm 0,284$ \\
\hline \multirow{5}{*}{ Пяята } & Контрольна група ( $=100)$ & $195,7 \pm 9,78$ & $56,0 \pm 3,08$ & $3,7 \pm 0,22$ & $4,5 \pm 0,24$ \\
\hline & 1.1 підгрупа (n = 90) & $197,0 \pm 10,63^{1}$ & $55,8 \pm 3,12^{1}$ & $3,7 \pm 0,19^{1}$ & $4,7 \pm 0,28^{1}$ \\
\hline & 1.2 підгрупа ( $\mathrm{n}=90)$ & $205,5 \pm 11,72^{2}$ & $59,8 \pm 3,35^{2}$ & $3,3 \pm 0,17^{2}$ & $4,6 \pm 0,26^{2}$ \\
\hline & 2.1 підгрупа (n = 100) & $193,2 \pm 10,623$ & $55,7 \pm 3,013$ & $3,7 \pm 0,213$ & $4,6 \pm 0,273$ \\
\hline & 2.2 підгрупа (n = 100) & $203,1 \pm 11,574$ & $58,1 \pm 3,314$ & $3,4 \pm 0,184$ & $4,9 \pm 0,294$ \\
\hline
\end{tabular}

ТАБЛИЦЯ 3.

ПОКАЗНИКИ ГОМЕОСТАЗУ ДОНОШЕНИХ НЕМОВЛЯТ, НАРОДЖЕНИХ МАТЕРЯМИ, ЯКІ ОДЕРЖУВАЛИ АБО НЕ ОДЕРЖУВАЛИ МК (M $\pm m$ )

1 Різниця достовірна $(p<0,01)$ відносно показника в контрольній групі

${ }^{2}$ Різниця достовірна $(p<0,01)$ відносно показника в 1.1 підгрупі

3 Різниця достовірна $(p<0,01)$ відносно показника в контрольній групі

४ Різниця достовірна $(\mathrm{p}<0,01)$ відносно показника в 2.1 підгрупі 


\begin{tabular}{|c|c|c|c|c|c|c|c|c|c|c|c|c|}
\hline \multirow{3}{*}{$\begin{array}{c}\text { Параметри активності } \\
\text { ферментів }\end{array}$} & \multicolumn{4}{|c|}{ Контрольна група, n = 100} & \multicolumn{4}{|c|}{1.1 підгрупа, $\mathrm{n}=90$} & \multicolumn{4}{|c|}{1.2 підгрупа, $\mathrm{n}=90$} \\
\hline & \multicolumn{4}{|c|}{ Доба після пологів } & \multicolumn{4}{|c|}{ Доба після пологів } & \multicolumn{4}{|c|}{ Доба після пологів } \\
\hline & 1 & 3 & 5 & 7 & 1 & 3 & 5 & 7 & 1 & 3 & 5 & 7 \\
\hline Сукцинатдегідрогеназа, г/л & $\begin{array}{c}15,32 \pm \\
0,85\end{array}$ & $\begin{array}{c}16,12 \pm \\
0,88\end{array}$ & $\begin{array}{c}14,21 \pm \\
0,78\end{array}$ & $\begin{array}{c}16,82 \pm \\
0,93\end{array}$ & $\begin{array}{c}15,77 \pm \\
0,80^{*}\end{array}$ & $\begin{array}{c}16,32 \pm \\
0,89^{*}\end{array}$ & $\begin{array}{c}15,29 \pm \\
0,87^{\star}\end{array}$ & $\begin{array}{c}15,33 \pm \\
0,83^{*}\end{array}$ & $\begin{array}{l}17,22 \pm \\
0,98^{* *}\end{array}$ & $\begin{array}{l}18,17 \pm \\
1,03^{\star *}\end{array}$ & $\begin{array}{l}16,43 \pm \\
0,87^{* *}\end{array}$ & $\begin{array}{l}15,29 \pm \\
0,88^{* *}\end{array}$ \\
\hline $\begin{array}{c}\text { а-гліцерофоссфатдегід- } \\
\text { рогеназа, г/л }\end{array}$ & $\begin{array}{c}9,87 \pm \\
0,55\end{array}$ & $\begin{array}{c}9,46 \pm \\
0,53\end{array}$ & $\begin{array}{c}9,44 \pm \\
0,52\end{array}$ & $\begin{array}{c}10,87 \pm \\
0,61\end{array}$ & $\begin{array}{l}9,07 \pm \\
0,48^{*}\end{array}$ & $\begin{array}{l}9,17 \pm \\
0,48^{\star}\end{array}$ & $\begin{array}{l}8,87 \pm \\
0,49^{*}\end{array}$ & $\begin{array}{l}9,57 \pm \\
0,54^{*}\end{array}$ & $\begin{array}{l}11,17 \pm \\
0,61^{\star *}\end{array}$ & $\begin{array}{l}10,49 \pm \\
0,58^{\star *}\end{array}$ & $\begin{array}{l}12,11 \pm \\
0,65^{\star \star}\end{array}$ & $\begin{array}{l}9,87 \pm \\
0,52^{\star *}\end{array}$ \\
\hline
\end{tabular}

У доношених немовлят від матерів, у яких був звичний викидень, ускладнений плацентарною недостатністю, і які одержували тільки патогенетичне лікування, виявлено підвищений рівень гемоглобіну, високий гематокрит, гіпоглікемію, зниження азотовидільної функції нирок, що спостерігалося протягом усього раннього неонатального періоду. Показники гомеостазу доношених немовлят представлені в таблиці 3. При індивідуальному аналізі мали місце більш високі показники гемоглобіну і гематокриту в немовлят з ознаками порушення адаптації.

Крім того, період адаптації немовляти супроводжувався високою напруженістю метаболіч- порівнянні $з$ контрольною групою зниження активності СДГ і $\alpha$-ГФДГ до 7-ї доби життя. У ензиматичній структурі лімфоцитів відзначалось виражене зменшення числа клітин з типовою активністю фрерменту. У немовлят підгруп $1.1 \mathrm{i}$ 2.1, матері яких одержували МK в комплексі 3 «основним лікуванням», була вірогідно висока активність СДГ і $\alpha$-ГФДГ у перші 3-5 діб після народження, що супроводжувалось збільшенням пула клітин з типовою активністю ферментів і числа клітин з високою активністю ферментів. Ці результати доводять, що застосування МК, підвищуючи окисно-відновні процеси в тканинах материнського організму,

ТАБЛИЦя 4.

ФЕРМЕНТАТИВНА АКТИВНІСТЬ СДГ I $\alpha$-ГФДГ У ЛІМФОЦИТАХ КРОВ НЕМОВЛЯТ В ЗАЛЕЖНОСТІ ВІД МЕТОДУ ЛІКУВАННЯ ВАГІТНИХ ЗІ ЗВИЧНИМ НЕВИНОШУВАННЯМ ВАГІТНОСТІ, УСКЛАДНЕНИМ ПЛАЦЕНТАРНОЮ НЕДОСТАТНІСТЮ

Різниця достовірна $(\mathrm{p}<0,01)$ відно показника в контрольній групі * Різниця достовірна $(p<0,01)$ відносно показника в 1.1 підгрупі

ТАБЛИЦЯ 5.

\begin{tabular}{|c|c|c|c|c|c|c|c|c|c|c|c|c|}
\hline \multirow{3}{*}{$\begin{array}{c}\text { Параметри активності } \\
\text { ферментів }\end{array}$} & \multicolumn{4}{|c|}{ Контрольна група, n = 100} & \multicolumn{4}{|c|}{2.1 підгрупа, n = 100} & \multicolumn{4}{|c|}{2.2 підгрупа, $\mathrm{n}=100$} \\
\hline & \multicolumn{4}{|c|}{ Доба після пологів } & \multicolumn{4}{|c|}{ Доба після пологів } & \multicolumn{4}{|c|}{ Доба після пологів } \\
\hline & 1 & 3 & 5 & 7 & 1 & 3 & 5 & 7 & 1 & 3 & 5 & 7 \\
\hline $\begin{array}{c}\text { Сукцинатдегідрогеназа, } \\
\text { г/л }\end{array}$ & $\begin{array}{c}15,32 \pm \\
0,82\end{array}$ & $\begin{array}{c}16,12 \pm \\
0,86\end{array}$ & $\begin{array}{c}14,21 \pm \\
0,77\end{array}$ & $\begin{array}{c}16,82 \pm \\
0,91\end{array}$ & $\begin{array}{c}15,63 \pm \\
0,83^{*}\end{array}$ & $\begin{array}{c}16,12 \pm \\
0,88^{*}\end{array}$ & $\begin{array}{c}15,28 \pm \\
0,85^{\star}\end{array}$ & $\begin{array}{c}15,42 \pm \\
0,86^{*}\end{array}$ & $\begin{array}{l}15,32 \pm \\
0,82^{* *}\end{array}$ & $\begin{array}{r}15,32 \pm \\
0,80^{* *}\end{array}$ & $\begin{array}{r}15,32 \pm \\
0,81^{* *}\end{array}$ & $\begin{array}{r}15,32 \pm \\
0,82^{* *}\end{array}$ \\
\hline $\begin{array}{c}\text { а-гліцерофоссратдегід- } \\
\text { рогеназа, г/л }\end{array}$ & $\begin{array}{c}9,87 \pm \\
0,54\end{array}$ & $\begin{array}{c}9,46 \pm \\
0,52\end{array}$ & $\begin{array}{c}9,44 \pm \\
0,49\end{array}$ & $\begin{array}{c}10,87 \pm \\
0,63\end{array}$ & $\begin{array}{l}9,48 \pm \\
0,51^{*}\end{array}$ & $\begin{array}{l}9,27 \pm \\
0,52^{*}\end{array}$ & $\begin{array}{l}9,00 \pm \\
0,51^{*}\end{array}$ & $\begin{array}{l}9,70 \pm \\
0,54^{*}\end{array}$ & $\begin{array}{l}11,17 \pm \\
0,63^{* *}\end{array}$ & $\begin{array}{c}10,87 \pm \\
0,59^{* *}\end{array}$ & $\begin{array}{l}12,00 \pm \\
0,67^{* *}\end{array}$ & $\begin{array}{l}9,77 \pm \\
0,53^{* *}\end{array}$ \\
\hline
\end{tabular}

них процесів. У цьому зв'язку можна припустити, що застосування МK сприяє поліпшенню адаптаційних реакцій у дітей у ранньому неонатальному періоді. Доказом цьому служать результати цитохімічного аналізу активності окислювально-відбудовних ферментів лімфоцитів. Результати аналізу фрерментативної активності СДГ і $\alpha$-ГФДГ, проведений у 100 немовлят від матерів з фрізіологічним перебігом вагітності проспективних груп дослідження, які під час вагітності одержували МK, і матерів, які її не одержували, представлені в таблицях 4 і 5. У здорових немовлят відмічено достовірне зростання активності досліджуваних фрерментів з 1-ї по 7-му добу життя, що вказує на активацію дихальних процесів і оптимізацію адаптаційно-метаболічних процесів. У немовлят 1.2 і 2.2 підгруп, матері яких одержували тільки «основне лікування», виявлена монотонність активації концентрації фрерментів, і достовірне, у опосередковано сприятливо впливає на стан організму плода і немовляти, оптимізуючи їх адаптаційні функції. Проведення МК немовлятам і сумісне застосування MK їх матерям сприяє поліпшенню і пролонгації терапевтичного ефректу.

\section{ВИСНОВКИ}

За наявності змін метаболічних процесів у вагітних із плацентарною недостатністю обгрунтованим є включення до комплексу лікувально-профрілактичних заходів схем препаратів МК. Висока ефективність МК доведена даними експериментальних, клініко-лабораторних і морфо-фрункціональних досліджень. Найбільш виражений лікувально-профілактичний ефрект виявлений у природних метаболітів - при регулярному їх застосуванні на ранніх строках вагітності.

Список літератури представлений на сайті www.reproduct-endo.com.ua 